\title{
Seed germination and vigor of different cowpea cultivars under salt stress
}

\author{
Francisco Vanies da Silva Sá ${ }^{1 *}$, Emanoela Pereira de Paiva², Salvador Barros Torres², \\ Marcos Eric Barbosa Brito', Narjara Walessa Nogueira², \\ Luciano Jonatas Gomes Frade', Rômulo Magno Oliveira de Freitas²

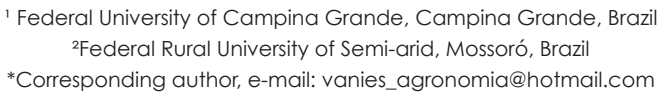

\begin{abstract}
Cowpea is an important food crop in underdeveloped regions, mainly for arid and semi-arid regions, where water scarcity and salinity are limiting factors. The identification of salt-tolerant varieties can assist the crop expansion and yield increase. Thus, the objective of this study was to assess the germination and vigor of seeds from cowpea cultivars (Vigna unguiculata L. Walp.), under salt stress. For this, the experiment was carried out at the Seed Analysis Laboratory, Federal Rural University of the Semiarid (UFERSA), Mossoró, RN, Brazil, from October to November, 2014. Ten cowpea cultivars (BRS Guariba; BRS Potengi; BRS Itain; BRS 17 Gurguéia; BRS Aracê; Paulistinha; Pingo de Ouro; BRS Maratanã; Costela de Vaca and Canapu Branco) were studied using a 10x2 factorial design under two water salinity levels $\left(0.0=\right.$ control and $\left.8.0 \mathrm{dS} \mathrm{m}^{-1}\right)$, in four replications with 50 seeds each. Germination and vigor were assessed through first count and standard test, root and hypocotyl length and total dry matter accumulation, in addition to salt tolerance index. Salt stress promoted growth reduction on cowpea cultivars and decreased the germination of the cultivars BRS Itain, Pingo de Ouro and Costela de Vaca. The BRS Aracê, Paulistinha and Canapu Branco cultivars are the most tolerant to salinity, while BRS Itain, BRS Gurguéia, Costela de Vaca and BRS Maratanã are the most sensitive to this stress during the germination phase.
\end{abstract}

Keywords: Vigna unguiculata, growth, water salinity

\section{Germinação e vigor de sementes de cultivares de feijão-caupi sob estresse salino}

\section{Resumo}

O feijão-caupi é uma cultura de grande importância alimentar, para regiões subdesenvolvidas, principalmente as regiões áridas e semiáridas do mundo, onde a escassez de água e a salinidade são fatores limitantes. Desse modo, a identificação de cultivares tolerantes à salinidade, pode auxiliar na expansão da cultura, além de aumentar o rendimento dos cultivos. Com isso, objetivouse avaliar a germinação e o vigor de sementes de cultivares de feijão-caupi (Vigna unguiculata L. Walp.) sob estresse salino. Para isso, o experimento foi realizado no Laboratório de Análise de Sementes da Universidade Federal Rural do Semi-Árido (UFERSA), Mossoró, RN, no período de outubro a novembro de 2014. Estudou-se usando o esquema fatorial $(10 \times 2)$ : dez cultivares de feijão-caupi (BRS Guariba; BRS Potengi; BRS Itain; BRS 17 Gurgueía; BRS Aracê; Paulistinha; Pingo de Ouro; BRS Maratanã; Costela de Vaca e Canapu Branco), sob dois níveis de salinidade da água $\left(0,0=\right.$ controle e $\left.8,0 \mathrm{dS} \mathrm{m}^{-1}\right)$, em quatro repetições de 50 sementes. A germinação e o vigor foram avaliados através da primeira contagem e teste padrão, comprimento da raiz e do hipocótilo, acúmulo de massa seca total, além do índice de tolerância à salinidade. O estresse salino reduziu o crescimento das cultivares de feijão-caupi, e germinação das cultivares BRS Itain, Pingo de Ouro e Costela de Vaca. As cultivares BRS Aracê, Paulistinha e Canapú Branco foram as mais tolerantes à salinidade, enquanto as BRS Itaim, BRS Gurgueía, Costela de Vaca e Maratanã mostram-se mais sensíveis.

Palavras-chave: Vigna unguiculata, crescimento, salinidade da água 


\section{Introduction}

Cowpea (Vigna unguiculata L. Walp.) is a very important food from the Fabaceae family, especially for underdeveloped areas of the world, due to the high protein content of its seeds (Akande, 2007). In Brazil, its cultivation is more expressive in the North and Northeast (semiarid areas) regions of the country, in which it is adapted to climate and soil conditions (Matos Filho et al., 2009). However, in recent years, this culture is attracting interest from growers from other regions of the country, increasing its expansion (Freire Filho et al., 2006). Furthermore, yield is considering low in the semiarid region, which can be attributed to the poor rainfall distribution and saline water characteristic.

Thus, semiarid climate cultivation faces problems with soil salt accumulation due to the low incidence of rain and soil profile salt leaching absence. Crop development is mainly affected by indirect problems, such as osmotic effect and ion toxicity, which are enhanced by high solar radiation (Munns \& Tester, 2008; Syvertsen \& Garcia-Sanchez, 2014), affecting seed germination and plant growth. However, crop production irrigation and the saline water use is a challenge that has been successfully overcome in several parts of the world, due to the use of salinity-tolerant species (Bezerra et al., 2010; Almeida et al., 2012; Sá et al., 2013).

Damages caused to seeds by salt stress are mainly related to increased osmotic pressure, which reduces water availability and affects wetting (Barreto et al., 2010). The consequences include reduction in germination percentage, emergence speed ", and changes on uniformity, plant size and yield (Scheeren et al., 2010; Massetto et al., 2014; Lima et al., 2015). In addition to the problems caused to the seeds, effects on seedling growth, such as specific ions toxicity due to reserves mobilization reduction and cell membrane disorder induction can be observed (Dantas et al., 2003).

Therefore, some studies have been developed with the cowpea crop searching for salinity-tolerant materials, which are mostly related to genotypes that do not reflect the currently used cultivars potential (Murillo-Amador et al., 2006; Santos et al., 2009; Almeida et al.
2012). Thus, the objective of this study was to assess cowpea seeds germination and vigor under salt stress.

\section{Material and Methods}

The experiment was conducted at the Seed Analysis Laboratory of The Federal Rural University of the Semiarid (UFERSA), Mossoró, RN, Brazil, from October to November, 2014. Seeds of cowpea cultivars were produced from October 2013 to July 2014, at the Federal University of Campina Grande (UFCG) experimental area,

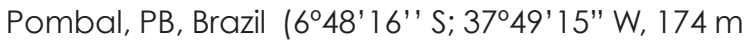
altitude) . The climate of the region $c$ is classified as hot and dry semiarid, with an average rainfall of $750 \mathrm{~mm} \mathrm{yr}^{-1}$ and $2000 \mathrm{~mm}$ of annual evaporation (Coelho \& Soncin, 1982).

Ten studied cowpea cultivars are part of a breeding program of Embrapa Mid-North (BRS Guariba; BRS Potengi; BRS Itaim; BRS 17 Gurgueía; BRS Aracê; Paulistinha; Pingo de Ouro; BRS Maratanã; Costela de Vaca and Canapu Branco), and were evaluated under two salinity levels $\left(0.0=\right.$ control and $\left.8.0 \mathrm{dSm}^{-1}\right)$, being one below and one above the crop salinity threshold (4.9 dS $\mathrm{m}^{-1}$ ) (Ayers \& Westcot, 1999), in a 10x2 factorial design, with treatments distributed in a completely randomized experimental design, with four replications and 50 seeds per plot.

The used irrigation solutions were prepared with salt addition to distilled water, using $\mathrm{NaCl}$-sodium chloride, which composes $70 \%$ of salt ions in irrigation water from small northeastern Brazil properties (Medeiros et al., 2003).

Seeds were placed in Germitest ${ }^{\circledR}$ paper rolls, 2.5 times moistened based on its dry weight, according to the treatment, and germinated on a Biochemical Oxygen Demand (B.O.D.) type incumbator, at $25^{\circ} \mathrm{C}$ and with 8 hours of light and 16 hours of darkness photoperiod. Counts were carried out in the fourth and eighth day after sowing, and the results were expressed as normal seedlings percentage (Brasil, 2009).

At the end of the germination test, each repetition normal seedlings primary root and shoot were measured with the aid of a ruler graduated in millimeters, and results were expressed in $\mathrm{cm}$ seedling ${ }^{-1}$. In order to determine the total dry matter (TDM), seedlings were kept in 
Kraft paper bags, placed in an oven with forced air circulation at $65{ }^{\circ} \mathrm{C}$ until reaching constant weight and weighed in analytical balance $(0.0001 \mathrm{~g})$, with results being expressed in $\mathrm{g}$ seedling ${ }^{-1}$ (Nakagawa, 1999).

With total dry matter production data, partitioned percentages between vegetative organs and salinity tolerance index were calculated, comparing saline treatment and control results $\left(C E w=0.6 \mathrm{dS} \cdot \mathrm{m}^{-1}\right)$, according to the following equation:

$$
I T(\%)=\frac{\text { Saline treatment TDM yield }}{\text { Control treatment TDM yield }} \times 100
$$

The total dry matter yield of the genotypes were used as the main parameter to determine materials tolerance to salt stress for the calculations.

Data were submitted to variance analysis ('F' test) and were grouped by Scott Knott's test according to genotype factor, and ' $t$ ' Student's test was used for the salinity factor, both at $5 \%$ of significance level, with the aid of SISVAR $B$ statistical software (Ferreira, 2011).

\section{Results and Discussion}

Increased water salinity affected the first germination count of all cowpea cultivars, with BRS Itaim and Pingo de Ouro being the most affected, with 44 and $41 \%$ of reduction compared to control, respectively. Similar germination results were obtained for the same cultivars, which with Costela de Vaca were the only affected, denoting their salt stress sensitivity (Table 1). This behavior is possibly related to the damage caused by increased osmotic pressure, promoting water availability reductions and affecting seed moisture (Barreto et al., 2010). Therefore, biochemical activities were inhibited and damage was caused to cell membranes due to salt excess, as explained by Taiz \& Zaiger (2013).

For BRS Guariba, BRS Potengi, BRS 17 Gurguéia, BRS Aracê, Paulistinha, BRS Maratanã and Canapu Branco cultivars, no difference was observed for the irrigation water salinity levelson germination (Table 1).

Table 1. Germination and germination first count for seeds of cowpea cultivars submitted to salt stress.

\begin{tabular}{|c|c|c|c|c|}
\hline \multirow{3}{*}{ Cultivars } & \multicolumn{2}{|c|}{ Germination (\%) } & \multicolumn{2}{|c|}{ First count (\%) } \\
\hline & \multicolumn{4}{|c|}{ Salinity $\left(\mathrm{d} S \mathrm{~m}^{-1}\right)$} \\
\hline & 0.0 & 8.0 & 0.0 & 8.0 \\
\hline BRS Guariba & $97 \mathrm{aA}$ & $96 a A$ & $97 \mathrm{aA}$ & $64 \mathrm{aB}$ \\
\hline BRS Potengi & $97 \mathrm{aA}$ & $98 \mathrm{aA}$ & $97 \mathrm{aA}$ & $66 \mathrm{aB}$ \\
\hline BRS Itaim & 87 bA & $81 \mathrm{CB}$ & 87 bA & $49 \mathrm{CB}$ \\
\hline BRS 17 Gurgueía & $100 \mathrm{aA}$ & $98 \mathrm{aA}$ & $100 \mathrm{aA}$ & $66 \mathrm{aB}$ \\
\hline BRS Aracê & $97 \mathrm{aA}$ & $95 \mathrm{bA}$ & $97 \mathrm{aA}$ & $63 \mathrm{bB}$ \\
\hline Paulistinha & $100 \mathrm{aA}$ & $99 \mathrm{aA}$ & $100 \mathrm{aA}$ & $67 \mathrm{aB}$ \\
\hline Pingo de Ouro & $100 \mathrm{aA}$ & $91 \mathrm{bB}$ & $100 \mathrm{aA}$ & $59 \mathrm{CB}$ \\
\hline BRS Maratanã & $100 \mathrm{aA}$ & $99 \mathrm{aA}$ & $100 \mathrm{aA}$ & $67 \mathrm{aB}$ \\
\hline Costela de Vaca & $99 \mathrm{aA}$ & $92 \mathrm{bB}$ & $99 \mathrm{aA}$ & $60 \mathrm{bB}$ \\
\hline Canapu Branco & $100 \mathrm{aA}$ & $99 \mathrm{aA}$ & $100 \mathrm{aA}$ & $67 \mathrm{aB}$ \\
\hline
\end{tabular}

For seedlings that germinated under $8.0 \mathrm{dS} \mathrm{m}^{-1}$ of salinity, it was possible to observe a reduction on shoot and root length, regardless the cultivar, when compared to control (Table 2). Based on the means that were grouped according to statistic analysis,, it was observed a formation of a group according to shoot length, indicating that BRS Itaim, BRS Potengi and BRS Aracê were the most sensitive to salinity, and BRS Guariba cultivars, BRS 17 Gurguéia, Paulistinha, Pingo de Ouro, BRS Maratanã, Costela de Vaca and Canapu Branco the most tolerant genotypes. Regarding the radicle length, the cultivar Canapu Branco obtained the best results, with only $28 \%$ of reduction in the radicle length, when compared to others that presented reduction ranging from 38 to $52 \%$, compared to control (Table 2).

Therefore, seed damage caused by osmotic effect affected cowpea seedlings; it is also believed that dramatic reductions on radicle growth are related to the toxic effects caused by specific ions $(\mathrm{NaCl})$, promoting membrane damage and hormonal and 
nutritional effects, such as biogeochemical sites activation and reserves consumption (Dantas et al., 2003; Sá et al., 2013; Taiz \& Zaiger, 2013; Syvertsen \& Garcia-Sanchez, 2014). However, increased root growth observed in the Canapu Branco cultivar probably occurred due to a tolerance mechanism expression, which aims to increase substrate exploration, promoting higher ion absorption selectivity and minimizing indirect consequences, such as osmotic effect and ions toxicity (Flowers \& Flowers, 2005; Sá et al., 2013).

The higher accumulation of total dry mass was observed for BRS Aracê, Paulistinha, Pingo de Ouro and Costela de Vaca cultivars in salt stress absence, and for BRS Aracê, Paulistinha, Pingo de Ouro and Canapu Branco in stress presence. For the other cultivars, drastic dry matter accumulation reductions were observed (Table 3). This fact indicates that salt stress affected cowpea seedlings carbohydrates accumulation. This was possibly due to a reduction of reserve polysaccharides and degradation of hydrolytic enzymes capacity (cotyledons), influencing the nutrition, which was confirmed by seedling growth reduction. Further biomass accumulation reductions in cowpea seedlings under salt stress ( $\mathrm{NaCl}$ ) were also verified by Santos et al. (2009) and Almeida et al. (2012).

Salinity had a significant effect on crop yield, reducing salt tolerance. Up to the level of $8.0 \mathrm{dS} \mathrm{m}^{-1}$, three genotype groups were formed: those that presented tolerance, such as BRS Aracê, Paulistinha and Canapu Branco, that presented tolerance indexes higher than $75 \%$; moderately tolerants, such as BRS Guariba, BRS Potegi and Pingo de Ouro, that presented tolerance between 70 and $75 \%$; and a sensitive group, composed by BRS Itaim, BRS Gurguéia, Costela de Vaca and BRS Maratanã, with tolerance indexes of less than $70 \%$, during germination and early growth phase (Table 3).

Table 2. Length of shoot and radicle of seedlings of different cowpea cultivars, germinated under salt stress.

\begin{tabular}{|c|c|c|c|c|}
\hline \multirow{3}{*}{ Cultivars } & \multicolumn{2}{|c|}{ Shoot length $(\mathrm{cm})$} & \multicolumn{2}{|c|}{ Radicle length $(\mathrm{cm})$} \\
\hline & \multicolumn{4}{|c|}{ Salinity $\left(\mathrm{d} \mathrm{S} \mathrm{m}^{-1}\right)$} \\
\hline & 0.0 & 8.0 & 0.0 & 8.0 \\
\hline BRS Guariba & $13.65 \mathrm{aA}$ & $3.90 \mathrm{aB}$ & $18.05 \mathrm{aA}$ & $8.58 \mathrm{bB}$ \\
\hline BRS Potengi & $11.60 \mathrm{bA}$ & $2.58 \mathrm{bB}$ & $15.05 \mathrm{bA}$ & $6.10 \mathrm{bB}$ \\
\hline BRS Itaim & $9.70 \mathrm{cA}$ & $2.28 \mathrm{bB}$ & $13.10 \mathrm{cA}$ & $7.53 \mathrm{bB}$ \\
\hline BRS 17 Gurgueía & $13.65 \mathrm{aA}$ & $4.00 \mathrm{aB}$ & $15.45 \mathrm{bA}$ & $7.45 \mathrm{bB}$ \\
\hline BRS Aracê & $9.48 \mathrm{cA}$ & $2.58 \mathrm{bB}$ & $12.95 \mathrm{aA}$ & $7.05 \mathrm{bB}$ \\
\hline Paulistinha & $8.33 \mathrm{dA}$ & $3.38 \mathrm{aB}$ & $10.70 \mathrm{dA}$ & $6.65 \mathrm{bB}$ \\
\hline Pingo de Ouro & $11.37 \mathrm{bA}$ & $3.75 \mathrm{aB}$ & $12.93 \mathrm{CA}$ & $6.73 \mathrm{bB}$ \\
\hline BRS Maratanã & $11.93 \mathrm{bA}$ & $4.30 \mathrm{aB}$ & $13.45 \mathrm{bA}$ & $5.60 \mathrm{bB}$ \\
\hline Costela de Vaca & $7.25 \mathrm{eA}$ & $3.40 \mathrm{aB}$ & $11.85 \mathrm{dA}$ & $7.30 \mathrm{bB}$ \\
\hline Canapu Branco & $11.95 \mathrm{bA}$ & $3.53 \mathrm{aB}$ & $16.20 \mathrm{bA}$ & $11.65 \mathrm{aB}$ \\
\hline
\end{tabular}

Table 3. Total dry mass and tolerance index of cowpea seedlings from cultivars germinated under salt stress.

\begin{tabular}{|c|c|c|c|c|}
\hline \multirow{3}{*}{ Cultivars } & \multicolumn{2}{|c|}{ Total dry mass (mg) } & \multicolumn{2}{|c|}{ Tolerance índex (\%) } \\
\hline & \multicolumn{4}{|c|}{ Salinity $\left(\mathrm{dS} \mathrm{\textrm {m } ^ { - 1 } )}\right.$} \\
\hline & 0.0 & 8.0 & 0.0 & 8.0 \\
\hline BRS Guariba & $22.96 \mathrm{bA}$ & $17.15 \mathrm{bB}$ & $100.0 \mathrm{aA}$ & $74.6 \mathrm{bB}$ \\
\hline BRS Potengi & $23.41 \mathrm{bA}$ & $17.00 \mathrm{bB}$ & $100.0 \mathrm{aA}$ & $72.6 \mathrm{bB}$ \\
\hline BRS Itaim & $21.65 \mathrm{bA}$ & $13.32 \mathrm{bB}$ & $100.0 \mathrm{aA}$ & $69.2 \mathrm{CB}$ \\
\hline BRS 17 Gurgueía & $17.97 \mathrm{cA}$ & $11.57 \mathrm{CB}$ & $100.0 \mathrm{aA}$ & $64.5 \mathrm{CB}$ \\
\hline BRS Aracê & $24.26 \mathrm{aA}$ & $18.91 \mathrm{aB}$ & $100.0 \mathrm{aA}$ & $78.3 \mathrm{aB}$ \\
\hline Paulistinha & $24.18 \mathrm{aA}$ & $18.61 \mathrm{aB}$ & $100.0 \mathrm{aA}$ & $75.2 \mathrm{aB}$ \\
\hline Pingo de Ouro & $27.90 \mathrm{aA}$ & $20.41 \mathrm{aB}$ & $100.0 \mathrm{aA}$ & $73.3 \mathrm{bB}$ \\
\hline BRS Maratanã & $23.11 \mathrm{bA}$ & $15.80 \mathrm{bB}$ & $100.0 \mathrm{aA}$ & $68.5 \mathrm{CB}$ \\
\hline Costela de Vaca & $25.98 \mathrm{aA}$ & $16.99 \mathrm{bB}$ & $100.0 \mathrm{aA}$ & $65.4 \mathrm{CB}$ \\
\hline Canapu Branco & $23.00 \mathrm{bA}$ & $19.28 \mathrm{aB}$ & $100.0 \mathrm{aA}$ & $84.0 \mathrm{aB}$ \\
\hline
\end{tabular}

to't' Student's test, both at $5 \%$ of probability. 
The identification of materials with potential tolerance to salinity during germination and initial growth phase is very important, since it can be used as a reference for the establishment of crops in regions with scarce water resources because of the presence of salts in irrigation water, such as the semiarid regions of Northeast Brazil (Medeiros et al., 2003), where cowpea crop are more expressive.

\section{Conclusions}

Salt stress promoted growth reduction on cowpea seedlings, and the decrease on germination of the cultivars BRS Itain, Pingo de Ouro and Costela de Vaca.

The BRS Aracê, Paulistinha and Canapu Branco cultivars are the most tolerant to salinity, while BRS Itain, BRS Gurguéia, Costela de Vaca and BRS Maratanã are the most sensitive during the germination phase.

\section{References}

Akande, S.R. 2007. Genotype by environment interaction for cowpea seed yield and disease reactions in the forest and derived savanna agro-ecologies of south-west Nigeria. AmericanEurasia Journal of Agricultural and Environmental Science 2: 163-168.

Almeida, W.S., Fernandes, F.R.B., Bertini, C.H.C.M., Pinheiro, M.S., Teófilo, E.M. 2012. Emergência e vigor de plântulas de genótipos de feijãocaupi sob estresse salino. Revista Brasileira de Engenharia Agrícola e Ambiental 16: 1047-1054.

Ayers, R.S., Westcot, D.W. 1999. A qualidade de água na agricultura. 2.ed. Campina Grande: UFPB. 153p. (Estudos FAO. Irrigação e Drenagem, 29). Tradução de Gheyi, H.R., Medeiros, J.F., Damasceno, F.A.V.

Bezerra, A.K.P., Lacerda, C.F., Hernandez, F.F.F. Silva, F.B., Gheyi, H.R. 2010. Rotação cultural feijão caupi/milho utilizando-se águas de salinidades diferentes. Ciência Rural 40: 1075-1082.

BRASIL. Ministério da Agricultura, Pecuária e Abastecimento. Regras para análise de sementes. Secretaria de Defesa Agropecuária. Brasília, DF: Mapa/ACS, 2009. 395p.

Dantas, J.P., Ferreira, M.M.M., Marinho, F.J.L., Nunes, M.S.A., Queiroz, M.F., Santos, T.A. 2003. Efeito do estresse salino sobre a germinação e produção de sementes de Caupi. Revista Agropecuária Técnica 24: 119-130.

Ferreira, D.F. 2011 . Sisvar: a computer statistical analysis system. Ciência e Agrotecnologia 35: 1039-1042.

Freire Filho, F.R., Rocha, M.M., Brioso, P.S.T., Ribeiro, V.Q. 2006. BRS Guariba: white-grain cowpea cultivar for the midnorthregion of Brazil. Crop Breeding and Applied Biotechnology 6: 175-178.

Lima, M.F.P., Porto, M.A.F., Torres, S.B., Freitas, R.M.O., Nogueira, N.W., Carvalho, D.R. 2015. Emergência e crescimento inicial de plântulas de albízia submetidas à irrigação com água salina. Revista Brasileira de Engenharia Agrícola e Ambiental 19: 106-112.

Masetto, T.E., Scalon, S.PQ., Rezende, R.K.S., Oba, G.C., Gambatti, M., Patrício, V.S. 2014. Germinação de sementes de Dimorphandra mollis Benth.: efeito de salinidade e condicionamento osmótico. Revista Brasileira de Biociências 12: 127-131.

Matos Filho, C.H.A., Gomes, R.L.F., Rocha, M.M., Freire Filho, F.R., Lopes, A.C.A. 2009. Potencial produtivo de progênies de feijão-caupi com arquitetura ereta de planta. Ciência Rural 39: 348-354.

Medeiros, J.F., Lisboa, R.A., Oliveira, M., Silva Júnior, M.J., Alves, L.P. 2003. Caracterização das águas subterrâneas usadas para irrigação na área produtora de melão da Chapada do Apodi. Revista Brasileira Engenharia Agrícola e Ambiental 7: 469-472.

Munns, R., Tester, M. 2008. Mechanisms of salinity tolerance. Annual Review of Plant Biology 59: 651-681.

Murillo-Amador, B., Troyo-Diéguez, E., GarcíaHernandez, J.L., López-Aguiar, R., Ávila-Serrano, N.Y., Zamora-Salgado, S., Rueda-Puente, E.O., Kaya, C. 2006. Effect of $\mathrm{NaCl}$ salinity in the genotypic variation of cowpea (Vigna unguiculata) during early vegetative growth. Scientia Horticulturae 108: 423-443.

Nakagawa, J. 1999. Testes de vigor baseados no desempenho das plântulas. In Krzyzanowski FC, Vieira Rd, França Neto Jb (Ed.). Vigor de sementes: conceitos e testes. Londrina: ABRATES, p.2.1-2.24.

Sá, F.V.S., Brito, M.E.B., Melo, A.S., Antônio Neto, P., Fernandes, P.D., Ferreira, I.B. 2013. Produção de mudas de mamoeiro irrigadas com água salina. Revista Brasileira Engenharia Agrícola Ambiental 17: 1047-1054.

Santos, P.R., Ruiz, H.A., Neves, J.C.L., Almeida, E.F., Freire, M.B.G.S., Freire, F.J. 2009. Germinação, vigor e crescimento de cultivares de feijoeiro em soluções salinas. Revista Brasileira de Engenharia Agrícola e Ambiental 13: 882-889. 
Scheeren, B.R., Peske, S.T., Schuch, L.O.B., Barros, A.C.A. 2010. Qualidade fisiológica e produtividade de sementes de soja. Revista Brasileira de Sementes 323: 35-41.

Syvertsen, J.P., Garcia-Sanchez, F. 2014. Multiple abiotic stresses occurring with salinity stress in citrus. Environmental and Experimental Botany 103: 128-137.

Taiz, L., Zeiger, E. 2013. Fisiologia vegetal. 5.ed. Porto Alegre: Artmed, 918p. 